\title{
Straw retention efficiently improves fungal communities and functions in the fallow ecosystem
}

\author{
Caifang Zhang ${ }^{1,2}$, Zhaoli Lin ${ }^{1,2}$, Youxiong Que ${ }^{1,2}$, Nyumah Fallah ${ }^{1,2}$, Muhammad Tayyab ${ }^{1,2}$, Shiyan Li1,2, Jun Luo ${ }^{1,2}$, \\ Zichu Zhang ${ }^{3}$, Ahmad Yusuf Abubakar ${ }^{1,2}$ and Hua Zhang ${ }^{1,2^{*}}$
}

\begin{abstract}
Background: Straw retention is a substitute for chemical fertilizers, which effectively maintain organic matter and improve microbial communities on agricultural land. The purpose of this study was to provide sufficient information on soil fungal community networks and their functions in response to straw retention. Hence, we used quantitative real-time PCR (qRT-PCR), Illumina MiSeq (ITS rRNA) and FUNGuild to examine ITS rRNA gene populations, soil fungal succession and their functions under control (CK) and sugarcane straw retention (SR) treatments at different soil layers $(0-10,10-20,20-30$, and $30-40 \mathrm{~cm})$ in fallow fields.

Result: The result showed that SR significantly enhanced ITS rRNA gene copy number and Shannon index at 0-10 $\mathrm{cm}$ soil depth. Fungi abundance, OTUs number and ACE index decreased with the increasing soil depth. The ANOSIM analysis revealed that the fungal community of SR significantly differed from that of CK. Similarly, significant difference was also observed between topsoil $(0-20 \mathrm{~cm})$ and subsoil $(20-40 \mathrm{~cm})$. Compared with CK, SR decreased the relative abundance of the pathogen, while increased the proportion of saprotroph. Regarding soil depth, pathogen relative abundance in topsoil was lower than that in subsoil. Besides, both sugarcane straw retention and soil depths (topsoil and subsoil) significantly altered the co-occurrence patterns and fungal keystone taxa closely related to straw decomposition. Furthermore, both SR and topsoil had higher average clustering coefficients (aveCC), negative edges and varied modularity.
\end{abstract}

Conclusions: Overall, straw retention improved a-diversity, network structure and fungal community, while reduced soil pathogenic microbes across the entire soil profile. Thus, retaining straw to improve fungal composition, community stability and their functions, in addition to reducing soil-borne pathogens, can be an essential agronomic practice in developing a sustainable agricultural system.

Keywords: Sugarcane straw retention, Soil profile, Fungal community, Network analysis, FUNGuild analysis

\footnotetext{
* Correspondence: 000q010025@fafu.edu.cn

'Key Laboratory of Sugarcane Biology and Genetic Breeding, Ministry of Agriculture, Fujian Agriculture and Forestry University, Fuzhou 350002, China

${ }^{2}$ College of Agriculture, Fujian Agriculture and Forestry University, Fuzhou 350002, China

Full list of author information is available at the end of the article
}

(c) The Author(s). 2021 Open Access This article is licensed under a Creative Commons Attribution 4.0 International License, which permits use, sharing, adaptation, distribution and reproduction in any medium or format, as long as you give appropriate credit to the original author(s) and the source, provide a link to the Creative Commons licence, and indicate if changes were made. The images or other third party material in this article are included in the article's Creative Commons licence, unless indicated otherwise in a credit line to the material. If material is not included in the article's Creative Commons licence and your intended use is not permitted by statutory regulation or exceeds the permitted use, you will need to obtain permission directly from the copyright holder. To view a copy of this licence, visit http://creativecommons.org/licenses/by/4.0/. The Creative Commons Public Domain Dedication waiver (http://creativecommons.org/publicdomain/zero/1.0/) applies to the data made available in this article, unless otherwise stated in a credit line to the data. 


\section{Background}

Fertilization is a crucial agricultural approach that not only improves plant nutrient storage but also simultaneously alters soil attributes and microbial communities [1-3]. In the past few decades, extensive fertilization, especially nitrogen fertilizer, has been used to raise sugarcane production to meet the growing sugar demand [4]. Although inorganic fertilization has a positive effect on sugarcane yield, on the other hand, it has unfavorable indirect effects on soil quality by causing soil acidification, enhancing soil pathogens, intensifying nitrification and leaching of nitrates [4-6]. In contrast, organic fertilization is an alternative approach to chemical fertilization to mitigate soil acidification and to improve soil nutrient status, thus ensuring sugarcane productivity [7-9].

Straw retention (SR) has an important role in soil aggregation, and nutrient availability, increasing soil microbial biomass and functional diversity $[10,11]$. Therefore SR is a preferred approach for better agricultural, environmental sustainability, and global biogeochemical cycles [12-14]. The soil microbiome plays a pivotal role in soil ecosystem process and is an important driving force for the biogeochemical cycle of basic elements such as nitrogen $(\mathrm{N})$ and carbon $(\mathrm{C})$. In particular, fungi play an essential role in the successful biotransformation of organic substrates in straw retention ecosystem. Topsoil $(0-20 \mathrm{~cm})$ holds greater microbial biomass and diversity. In contrast, a high subsoil volume (below $20 \mathrm{~cm}$ ) on a depth-weighted basis also causes much microbial abundance and diversity [15-19]. Soil microbial composition changes with increasing soil depth, while microbial diversity generally declines with depth [20, 21]. Saprophytic fungi greatly participate in the nutrient cycle in terrestrial ecosystems, while symbiotic fungi are beneficial to the health, nutrition and quality of most crops [22]. Research has shown that rice straw input positively impacts soil biogeochemistry and can improve soil fertility and fungal community diversity [23].

High throughput sequencing (HTS) has been employed to investigate fungal community composition in soil, however, our understanding of the function and network of fungal community in a fallow straw retention system is very limited [24]. Furthermore, no-tillage and traditional agricultural systems have significant differences in soil fungal communities [25], but little is known about fungal communities' response to soil depth in sugarcane cultivation system.

FUNGuild is a novel tool for estimating functional diversity of fungal communities and also for comprehensively exploring fungal communities from an ecological perspective [26]. The fungal OTUs from HTS can be apportioned into 3 trophic modes and 12 guilds based on a database. LaMondia et al. documented that straw mulch did not affect the potato early dying disease, nematodes, or tuber yield [27]. However, many researchers reported that straw retention can enhance the soil's ability to resist major plant diseases [28, 29]. For example, Donovan et al. mentioned that crop residues retention increased soil ability to resist the presence of crown rot of wheat [28]. Therefore, the importance of fungal pathogens to animals and plants can not be ignored. Many researchers have extensively studied the effect of straw retention on the composition of soil microbial communities in agricultural soils [30-32]. However, understanding of the unusual fungal diversity and its complex interactions with crop residues in farmland is still limited. The interaction of fungi with soil carbon and sugarcane roots in different soil profiles favors fungal taxa with diverse life-history strategies. For instance, the abundance of plant roots and carbon in soil surface can produce a diverse symbiotrophs and saprotrophs communities, while subsoil, which are relatively low in carbon, can select discrete symbiotrophs and pathotrophs communities. In addition, shifts in fungal community composition and diversity in different soil profiles can be reflected in the unique species patterns and interactions in the fungal network.

Network analysis is essential to understand better the complex webs of fungus associations, which provides crucial insights into biological systems. Information on network structure (topology) is used to categorize "hub" species that are associated with many other species within networks depicting multiple species hostsymbiont relationships [33-35]. These hubs with broad host/symbiont ranges are essential for modulating different ecological processes within a community $[36,37]$. Researchers have used HTS technology to record information about fungal communities associated with plants [38, 39]. Identifying the hub microbial species among thousands of other species in the network has become a significant approach to understand ecosystem-scale phenomena.

Therefore, more understanding of fungal distribution patterns in soil profiles and fundamental mechanisms must update our current knowledge and future predictions of straw retention function. Accordingly, we hypothesize that soil depth and straw retention play a crucial role in changing the fungal community composition, network structure and trophic modes of keystone taxa. To investigate this, we analyzed soil fungal communities in response to straw retention in different soil profiles using MiSeq sequencing of fragments of the fungal internal transcriptional spacer (ITS).

\section{Results \\ qRT-PCR}

The qRT-PCR results of fungal ITS rRNA gene copies showed that exponentially distributed fungal communities 
on both CK and SR along with the soil depth. In soil depth, $0-10 \mathrm{~cm}$, the number of ITS rRNA copies in SR was significantly higher than $\mathrm{CK}(p<0.05)$. Meanwhile, both CK and SR treatments in $0-10 \mathrm{~cm}$ soil layer were significantly higher than in other soil layers (10-20, 20-30 and $30-40 \mathrm{~cm})(p<0.05)$ (Fig. 1). Two-way ANOVA interaction analysis showed that soil depth was the main factor affecting fungal abundance (Table S2).

\section{Alpha diversity}

A total of 960,252 (average of 40,011) filtered fungal readings were obtained from each soil sample (Table S3). Additionally, Good's coverage values ranged from 98 to $99 \%$ at $97 \%$ similarity cutoff. The result indicated that there were sufficient sequence reads to capture fungal richness and diversity from all soil samples. Compare to CK, OTUs number and ACE index of SR did not show a significant difference in all layers, however, the Shannon index was higher in $0-10 \mathrm{~cm}$ soil depth $(p<0.05)$ (Table 1). In CK and SR, the OTUs number and ACE index reduced with soil depth. However, in SR treatment, the OTUs number was higher in $0-10 \mathrm{~cm}$ than $30-40$ cm soil depth $(p<0.05)$, while the ACE index in soil layer $0-10 \mathrm{~cm}$ was significantly higher relative to that in $10-20 \mathrm{~cm}$ and $30-40 \mathrm{~cm}$ soil depths $(p<0.05)$. Multivariate ANOVA analysis revealed that soil depths significantly influence OTUs number and ACE index $(p<0.05)$ (Table 1).

\section{Relative abundance of dominant Phyla}

The relative abundance of Ascomycota (23.4-50.0\%) and Basidiomycota (1.4-9.8\%) was higher in the soil layer (0-
$40 \mathrm{~cm}$ ), followed by Glomeromycota (1.0-4.0\%), Mortierellomycota (0.4-3.0\%) and Chytridiomycota (0.0-3.4\%) (Fig. 2). In CK treatment, the phylum Ascomycota was enhanced with increasing soil depths (Fig. 2a). However, the abundance of Ascomycota in SR treatment was evenly distributed in various soil depths, ranging from $28.7-37.5 \%$ (Fig. 2b). In CK treatment, Basidiomycota relative abundance increased with soil depth, while the SR treatment Basidiomycota revealed a decreasing trend. In CK treatment, at $0-10 \mathrm{~cm}$ soil profile, Basidiomycota decreased compared with SR treatment $(p<0.05)$ (Table S4). Moreover, in CK, the relative abundance of Glomeromycota significantly increased in $0-10 \mathrm{~cm}$ than $30-40 \mathrm{~cm}$ soil layer $(p<0.05)$. Compared to SR in $30-40 \mathrm{~cm}$ soil layers, Chytridiomycota relative abundance was 44.57 times more than in CK treatment. Compared to CK, SR application led to a significant increase of Cercozoa in $0-10 \mathrm{~cm}$ soil depth $(p<0.01)$.

\section{Community Structure, Variation, and Determinants}

The NMDS based on unweighted UniFrac analysis at the OTU level revealed that fungal community similarity distance was influenced by both sugarcane straw retention and different soil depths (Fig. 3a). The analysis of similarities (ANOSIM) further confirmed significant differences between $\mathrm{CK}$ and $\mathrm{SR}(\mathrm{R}=0.66, P<0.02)$. Additionally, the fungal community in topsoil $(0-20 \mathrm{~cm})$ varied from that subsoil $(20-40 \mathrm{~cm})(\mathrm{R}=0.54, P<0.004)$ (Table S5). The analysis of VIF filtered the high Collinear factor TC and DON. The db-RDA was used at the OTU level to measure the effect of edaphic factors on fungal community composition, which demonstrated

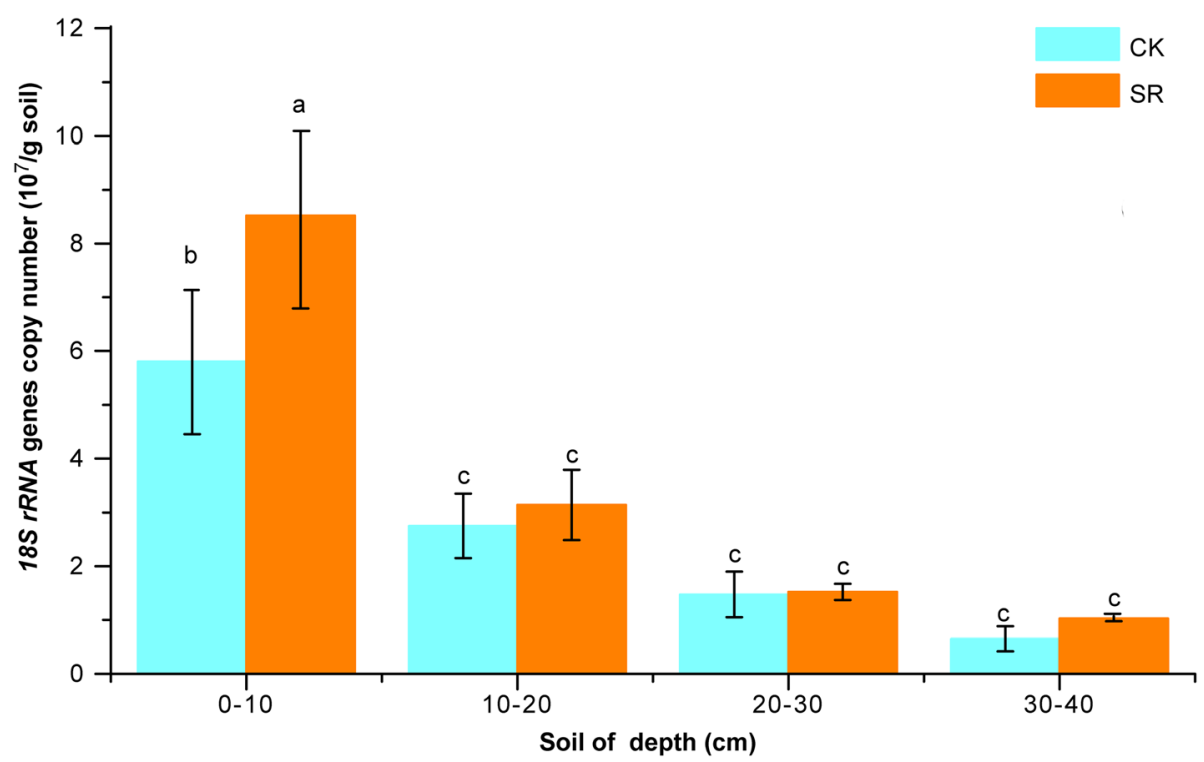

Fig. 1 The copies number of ITS rRNA gene in four soil depths $(0-40-\mathrm{cm})$ under sugarcane straw retention (SR) treatment compared to control (CK). Error bars in the histogram with different lowercase letters show significant differences between treatments (Tukey test, $n=3, p<0.05$ ) 
Table 1 Alpha diversity index

\begin{tabular}{llllll}
\hline Treatment & Depth & OTUs_num & ACE_index & Shannon_index & Coverage \\
\hline CK & $0-10$ & $1519.33 \pm 87.82 \mathrm{ab}$ & $2153.91 \pm 70.83 \mathrm{ab}$ & $3.96 \pm 0.34 \mathrm{c}$ & 0.99 \\
CK & $10-20$ & $1612.33 \pm 68.60 \mathrm{ab}$ & $2130.15 \pm 70.47 \mathrm{ab}$ & $4.68 \pm 0.23 \mathrm{abc}$ & 0.99 \\
CK & $20-30$ & $1541.00 \pm 91.15 \mathrm{ab}$ & $1932.04 \pm 167.98 \mathrm{abc}$ & $4.69 \pm 0.60 \mathrm{abc}$ & 0.99 \\
CK & $30-40$ & $1041.33 \pm 140.88 \mathrm{c}$ & $1511.80 \pm 126.94 \mathrm{c}$ & $4.83 \pm 0.15 \mathrm{abc}$ & 0.99 \\
SR & $0-10$ & $1671.33 \pm 22.70 \mathrm{a}$ & $2202.85 \pm 50.09 \mathrm{a}$ & $5.11 \pm 0.15 \mathrm{a}$ & 0.98 \\
SR & $10-20$ & $1332.33 \pm 102.49 \mathrm{abc}$ & $1635.66 \pm 136.23 \mathrm{bc}$ & $5.02 \pm 0.12 \mathrm{ab}$ & 0.99 \\
SR & $20-30$ & $1343.67 \pm 100.75 \mathrm{abc}$ & $2008.35 \pm 184.09 \mathrm{abc}$ & $4.88 \pm 0.27 \mathrm{abc}$ & 0.98 \\
SR & $30-40$ & $1261.00 \pm 273.58 \mathrm{bc}$ & $1548.86 \pm 386.96 \mathrm{c}$ & $4.12 \pm 0.38 \mathrm{bc}$ & 0.99 \\
& Treatment & 0.08 & 0.43 & 1.12 & 0.68 \\
\end{tabular}

Alpha diversity index at $0-40-\mathrm{cm}$ depth under sugarcane straw retention (SR) treatment compared to control (CK). Different letters indicate significant differences between samples (Tukey test, $p<0.05)$. Values are mean \pm standard errors $(n=3)$. Treatment: CK SR. Depth: soil of depth in 0-10, 10-20, 20-30, 30-40 cm. Multivariate ANOVA for the effects of straw retention and soil depth on number of OTUs number, ACE index, Shannon index

${ }^{a}$ represent the level of significance at 0.05

that $\mathrm{pH}\left(\mathrm{R}^{2}=0.46, P=0.002\right)$, AK $\left(\mathrm{R}^{2}=0.66, P=0.001\right)$ and $\mathrm{TN}\left(\mathrm{R}^{2}=0.47, P=0.03\right)$ were the major factors altering the fungal community structure (Fig. 3b).

\section{Fungal function prediction}

FUNGuild was used to analyze the metabolic pathways of soil fungi. Using an ecological guild and trophic mode, the fungi were classified in both treatments with different soil depths. Overall, a total of $29.14 \%$ of OTUs were classified as trophic modes with pathogenic, saprotrophic, and symbiotrophic, while the rest were not assigned. Saprotroph was the most observed fungi taxa in the samples. The relative abundance of saprotroph, and symbiotroph categories in CK treatment (18.90 and $6.57 \%$, respectively) were lower than that in SR treatment (20.06 and 5.62\%, respectively), while pathogen in
CK (16.26\%) was higher than in SR (7.60\%) (Table S6). The proportion of the saprotroph category of dung saprotroph-plant saprotroph-wood saprotroph in SR treatment was significantly higher compared with CK treatment $(P<0.05)$ (Fig. 4a). The proportion of pathogen category of the fungal parasite in SR was lower than in the CK $(P<0.05)$. Different soil depths also varied the trophic modes. The relative abundance of pathogen and saprotrophic in topsoil depth $(7.51$ and $18.73 \%$, respectively) were lower than subsoil (16.36 and 20.24\%, respectively). Moreover, the relative abundance of symbiotroph in topsoil (8.04\%) was higher than subsoil (4.16\%). Arbuscular mycorrhizal (AM) and endophyteplant pathogen relative abundance in topsoil were significantly higher compared to subsoil $(p<0.05)$ (Fig. 4b). On the other hand, dung saprotroph-endophyte-plant
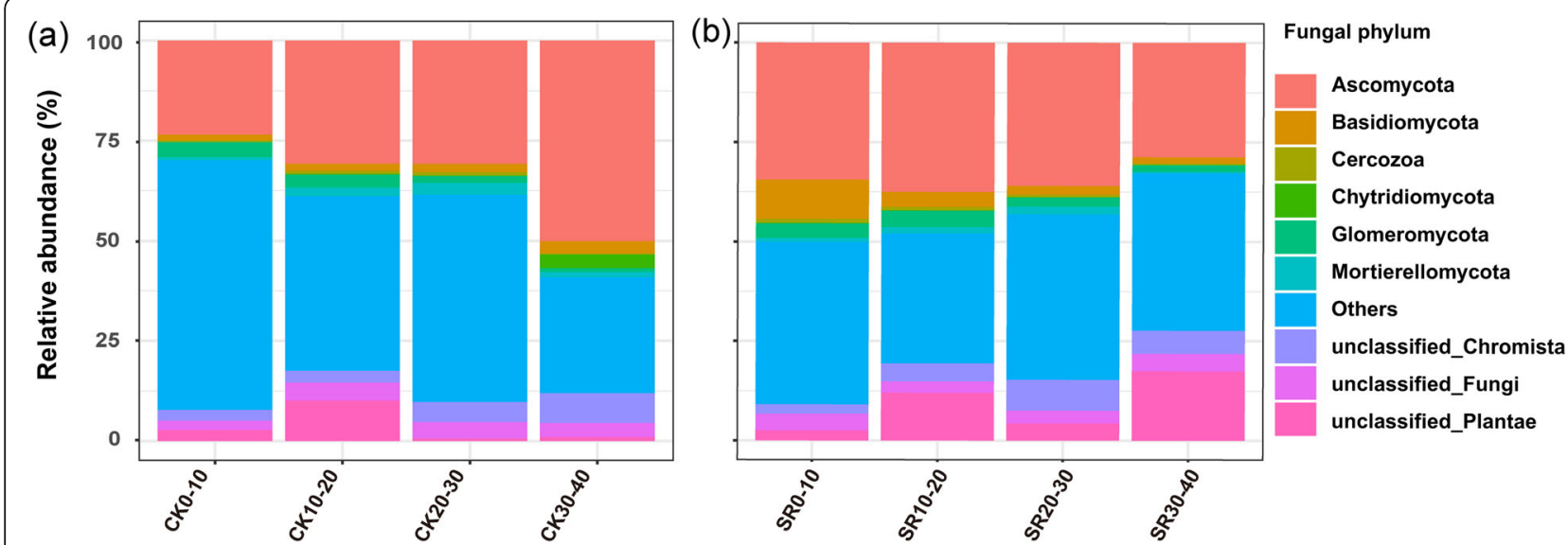

Fig. 2 Relative abundances of the top 10 fungal phyla (relative abundance $>0.04 \%$ ) at different depths, $\mathbf{a}$ in control (CK) treatments, and $\mathbf{b}$ sugarcane straw retention (SR). "Others" refers to those identified phyla that were beyond the top 10 phyla. CK, control; and SR, sugarcane straw retention 

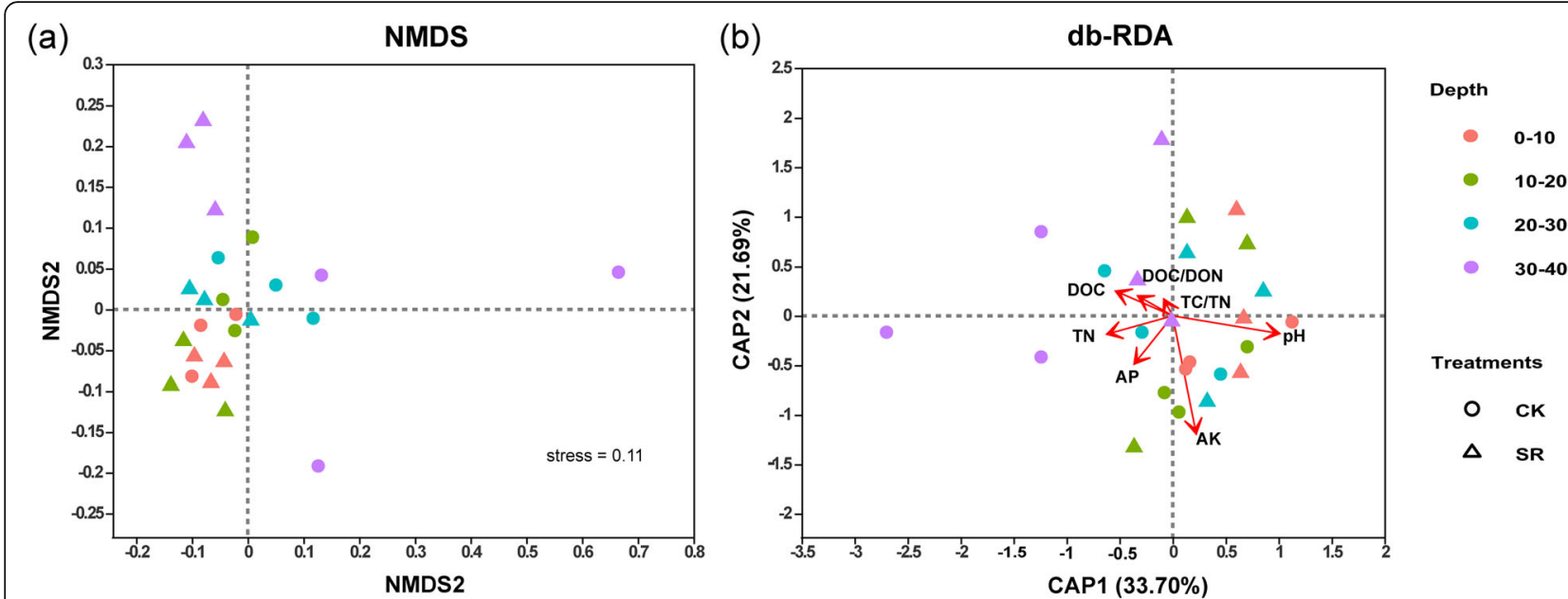

Fig. 3 Analysis of (a) nonparametric multidimensional scaling (NMDS) and (b) distance-based Redundancy analysis (db-RDA) depicting fungal communities in different soil profiles (0-10, 10-20, 20-30, and 30-40-cm). CK, control; SR, sugarcane straw retention

pathogen, animal pathogen-fungal parasite-undefined saprotroph, plant pathogen-undefined saprotroph, and endophyte-plant pathogen-wood saprotroph in topsoil diminished significantly compared to subsoil $(p<0.05)$. Compared to CK in $0-20 \mathrm{~cm}$ soil layers, the relative abundance of dung saprotroph-plant saprotroph-wood saprotroph and undefined saprotroph increased in SR, while the relative abundance of undefined saprotrophwood saprotroph decreased in SR (Fig. S1). However, compared to CK in $20-40 \mathrm{~cm}$ soil layer, SR showed no significant difference.

\section{Fungal network}

Differences were observed between the two networks of fungal communities under straw retention and different soil profiles. The total nodes and edges in CK (292 and 410, respectively) were lower than in SR (299 and 412, respectively) (Fig. 5a, b). Meanwhile, negative edges and

(a)

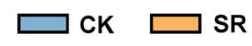

Dung Saprotroph_Plant Saprotroph_Wood Saprotroph Fungal Parasite
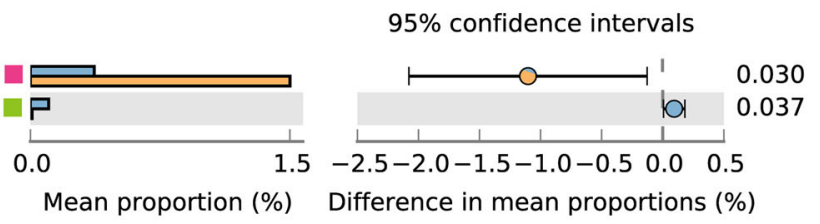

(b)
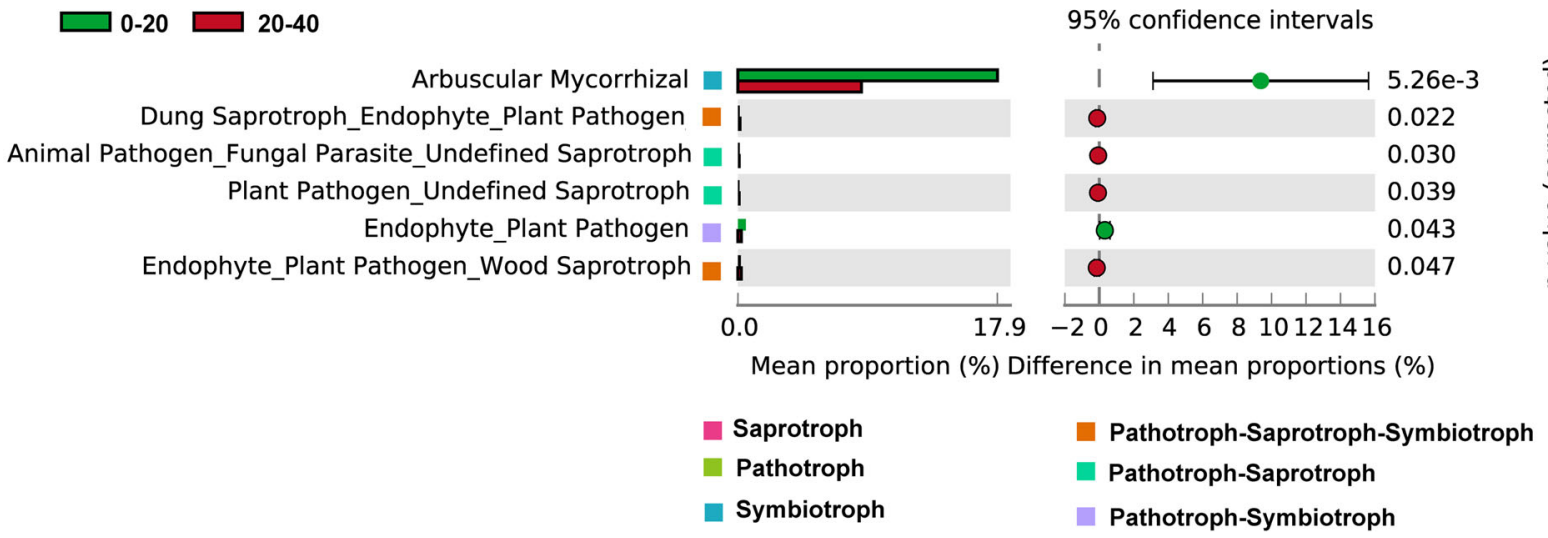

$95 \%$ confidence intervals Fig. 4 Extended error bar graphs indicate the significant difference of fungal functional guilds at level 2 (a) straw retention treatment and (b) in
topsoil $(0-20 \mathrm{~cm})$ and subsoil $(20-40 \mathrm{~cm})(p<0.05$, average proportion, $n=3)$. The points depict variations between the "CK" and "SR"; between topsoil $(0-20 \mathrm{~cm})$ and subsoil $(20-40 \mathrm{~cm})(p<0.05$, average proportion, $n=3)$. The points depict variations between the "CK" and "SR"; between
" $0-20 \mathrm{~cm}$ " and " $20-40 \mathrm{~cm}$ " depths, the values on the right-hand indicate the $p$-values obtained from the Welch t-test. a CK, control; SR, sugarcane straw retention 


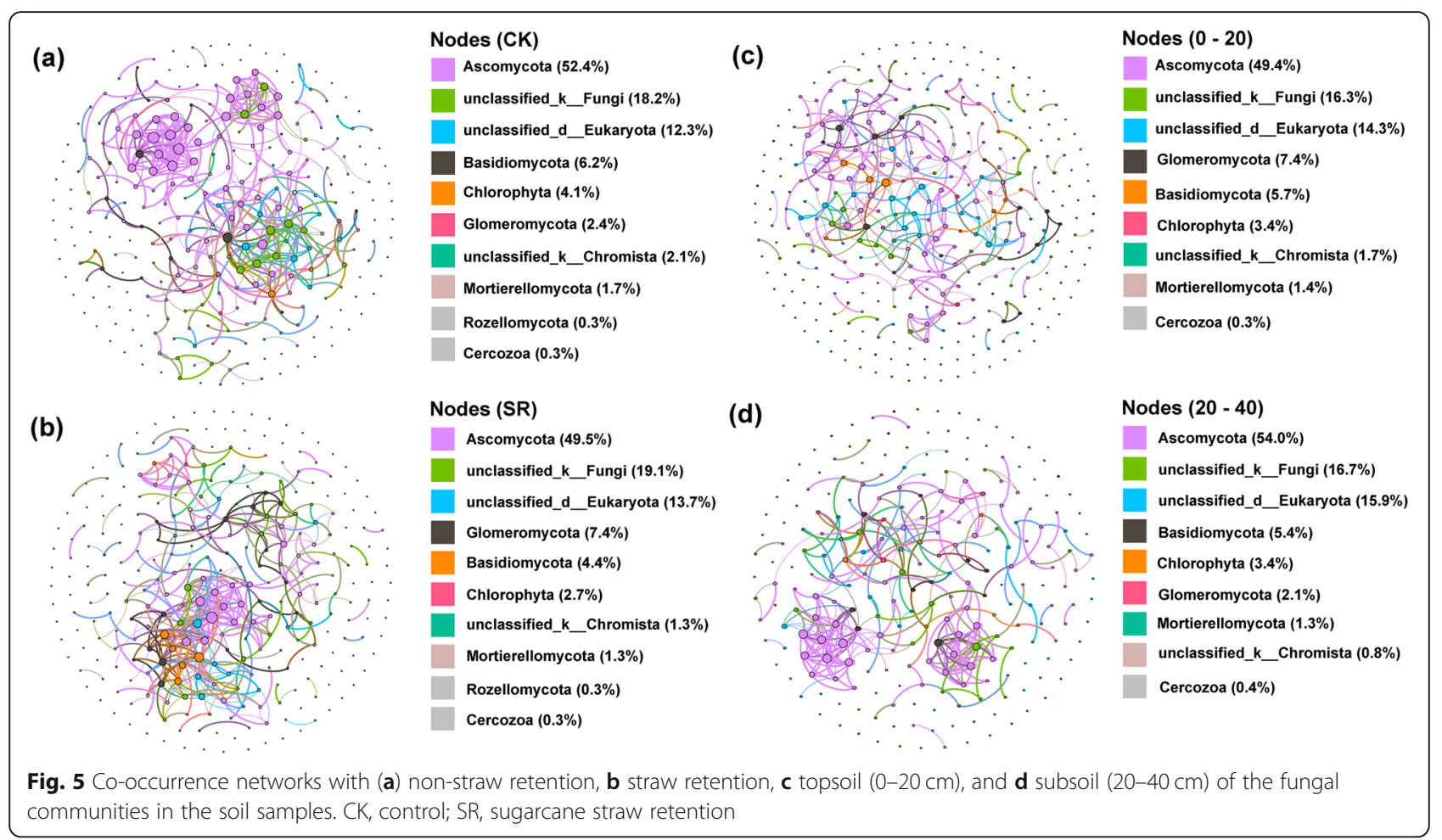

modularity in CK (17.32\%, 0.97, respectively) were lower than SR (22.82\%, 1.04) (Table S7). The relationships between nodes for each phylum pair were totaled to assess the potential interactions among the main phyla. The analysis of network topological properties revealed that SR showed a higher network average clustering coefficients (aveCC) than the CK treatment. The average path distance (GD) showed a decreasing trend from CK to SR treatment in fungal communities. In CK treatment, the nodes in the network were assigned to seven fungal phyla. At the phyla level, Ascomycota was widely distributed, representing $53 \%$ of all nodes. Nodes distribution was modularized, and clustered into 130 modules, with the majority of the nodes associated with Ascomycota. Based on betweenness centrality scores, the top four genera identified as keystone taxa were Alternaria, unclassified-o-Hypocreales, unclassified-oBranch06 and Plectosphaerella, which could be assorted into Pleosporales, Hypocreales, Branch06 and Glomerellales orders respectively and also into a single Ascomycota phylum. The trophic mode of Alternaria and Plectosphaerella were associated with pathotrophsaprotroph-symbiotroph and pathotroph, respectively (Table S8). In SR treatment, the nodes in the network were assigned to seven fungal phyla. Similarly, the phylum Ascomycota was widely distributed, accounting for $50 \%$ of all nodes. After the distribution of nodes was modularized, nodes were grouped into 150 modules. The top four genera included four keystone taxa, Trichoderma, Scutellinia,
Plectosphaerella and Claroideoglomus. The former three belonged to Hypocreales, Pezizales, Glomerellales orders and the same Ascomycota phylum, while the last one was associated with Glomerales order and Glomeromycota phylum. Trichoderma and Scutellinia were demonstrated with saprotroph, while Plectosphaerella and Claroideoglomus were demonstrated an association with pathotroph and symbiotroph, respectively. The total nodes and edges in topsoil (350 and 641, respectively) were higher than those in subsoil (239 and 511, respectively) (Fig. 5c, d), whereas average degree (avgK) 、 aveCC and GD in topsoil (3.66, 0.70 , and 6.43 , respectively) were lower than those in subsoil (4.28, 0.71, and 8.05) (Table S7). Negative edges and modularity in subsoil (9.59\%, 1.03, respectively) were lower than those in topsoil $(14.20 \%, 1.61$, respectively). Furthermore, in topsoil, the top four genera identified as keystone taxa were Clitopilus and Auricularia belonging to Agaricales and Auriculariales orders and Basidiomycota phylum, Staphylotrichum and Pyrenochaetopsis belonging to Sordariales and Pleosporales orders and Ascomycota phylum. Clitopilus, Auricularia and Staphylotrichum were saprotroph, Pyrenochaetopsis was pathotroph-saprotroph-symbiotroph (Table S8). In the subsoil, keystone taxa were Abortiporus belonging to Polyporales order and the phylum of Basidiomycota, and Trebouxia was related to Trebouxiales order and Chlorophyta phylum. Besides, unclassified-o-Branch06 and unclassified-f-Didymellaceae demonstrated an association with the phylum of Ascomycota, which belongs to 
Branch06 and Pleosporales orders. And Abortiporus was associated with saprotroph. Compared to CK at $0-20 \mathrm{~cm}$, the edges and modularity increased in SR, while positive edges decreased in SR (Fig. S2a; b) (Table S7). Compared to $\mathrm{CK}$ at $20-40 \mathrm{~cm}$, the edges and avgK decreased in SR (Fig. S2c; d) (Table S7).

\section{Pearson's correlation between soil attributes and relative} abundance of soil fungal taxa

Pearson's correlation coefficients indicated that the keystone taxa of a network (Order) correlated with multiple soil properties. The keystone taxa were from network (order) in both CK and SR treatments, as well as different soil depths (topsoil and subsoil). In CK treatment, soil TN and DOC were significant negative correlation with Hypocreales $(p<0.05)$, however, DOC/DON revealed positive correlation as well (Fig. 6a). Hypocreales revealed an association with pathotroph - saprotroph - symbiotroph trophic mode (Table S9). TC and TC/TN were negatively and significantly related to Branch06 $(p<0.05)$. In SR treatment, AP was negatively and significantly connected with Glomerales $(p<0.05)$ (Fig. $6 \mathrm{~b})$, which was associated with symbiotroph. In the topsoil DOC/DON revealed a positive and significant relationship with Auriculariales and Sordariales $(p<0.05$ and $p<0.01$, respectively), which were saprotroph (Fig. 6c). Subsoil nutrient revealed no significant association with keystone taxa (Fig. 6d). The keystone taxa were from the network (genus), which were correlated with $\mathrm{C}$ and $\mathrm{N}$ cycle (Fig. S3). Soil pH was significantly positively correlated with unclassified-Hypocreales. Unclassified-o-Branch06 and Claroideoglomus were negatively correlated with soil $\mathrm{C}$ and $\mathrm{N}$ cycle. However, Clitopilus and Trebouxia were positively correlated with soil $\mathrm{C}$ and $\mathrm{N}$ cycle. Furthermore, Plectosphaerella was negatively correlated with $\mathrm{TC} /$ $\mathrm{TN}$ in CK, however, Plectosphaerella was positively correlated with DOC/DON in SR.

\section{Discussion}

Research shown that straw retention can alter soil microbial distribution throughout the soil profile [40]. Similarly, in this study showed that straw retention improved fungal abundance, especially in topsoil, while it decreased exponentially with increasing soil depth. The previous study has shown that fungi dominated litter-C decomposition, and fungal community composition varied within different soil profiles and controlled resource availability [41]. It is well documented that different organic materials, especially wheat straw, farm manure [42], and cow manure compost, change microbial biomass and agricultural land activity [2]. A similar study showed that straw retention positively impacts cucumber seedlings growth by increasing soil microbial

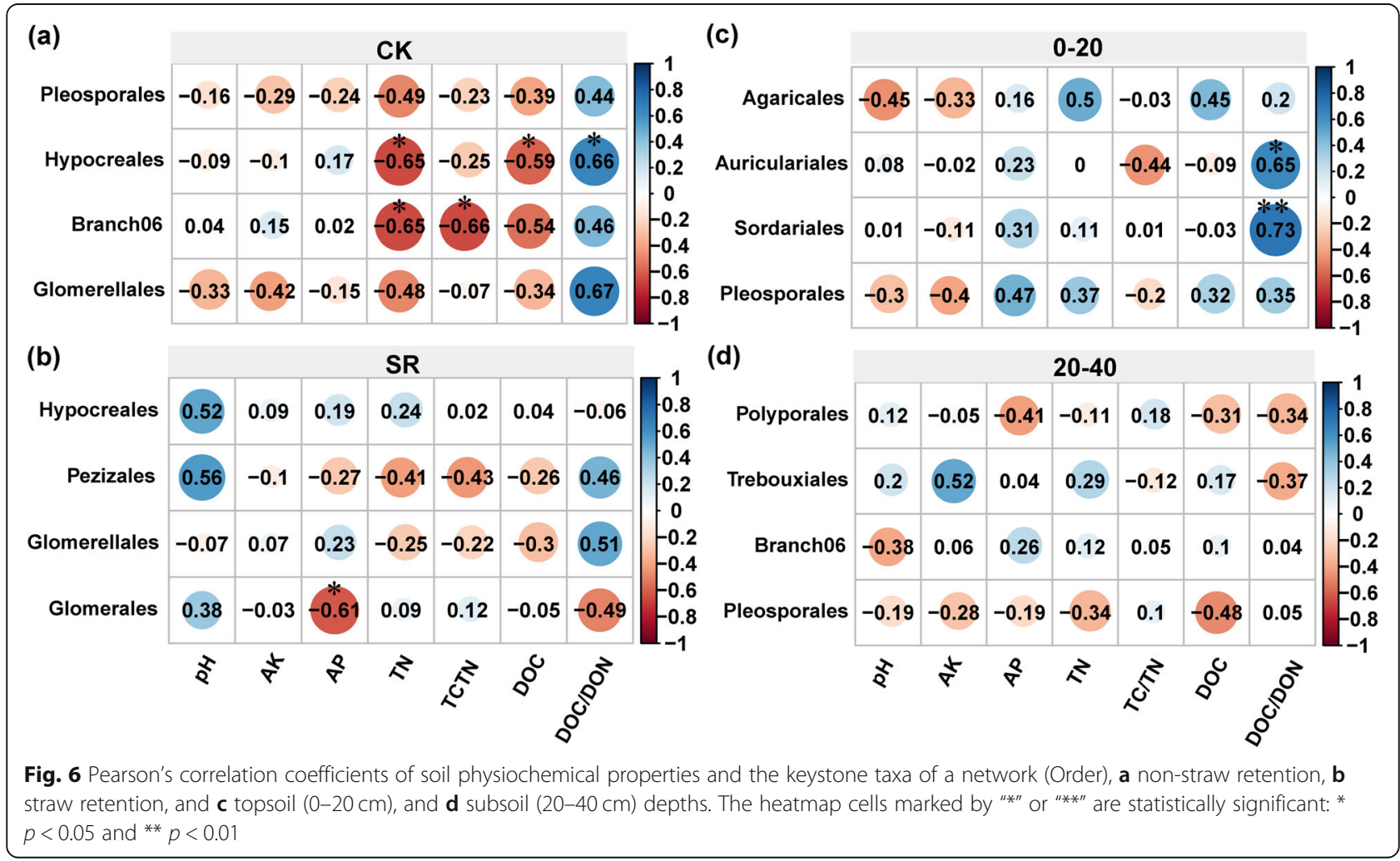


biomass and changing soil microbial community structure [43].

Increased biodiversity can promote the stability of ecosystems and enhance the mix of basic microbial functions and activities [44]. Alpha fungus diversity decreased with increasing soil depth [45], which is supported by our results that straw retention decreased fungal diversity at a soil depth of $0-30 \mathrm{~cm}$ than $0-10 \mathrm{~cm}$. Compared with CK, Fungal richness showed no obvious change in response to straw retention, while soil depth was the main driving force to change fungal diversity, which is consistent with previous studies [41, 46, 47].

Fungi play a key role in decomposing recalcitrant substrates $[48,49]$, and their abundance changed under the combined effect of treatment and soil depth. Ascomycota plays a key role in the decomposition of organic substrates $[30,32,50]$ and is found to be the main phyla of fungi. Furthermore, SR improved the relative abundance of Ascomycota at different soil depths. Straw retention significantly improved Basidiomycota abundance, which is consistent with previous findings [51]. As an important decomposer, Basidiomycota produces enzymes (e.g, peroxide) to degrade recalcitrant plant compounds, such as cellulose and lignin [50]. A previous study showed that straw retention could increase carton content and cellulase activity [18].

Funguild analysis revealed that straw retention not only altered saprotroph (dung saprotroph-plant saprotrophwood saprotroph) but also suppressed pathogenic (fungal parasites) (Fig. 4a). A similar phenomenon was detected in the composting of Chinese herb residues [52]. Many studies have confirmed that saprotrophs are involved in the decomposition process [53], and pathogenic fungi commonly acquire nutrients for invading host cells, so they are known to pose a threat to other fungal community members [54]. Thus, the result showed that straw retention can improve soil nutrient cycles and health. Many investigations indicated that between plant roots and a diverse array of mutualistic endophytic symbionts enhance crop quality, health, and soil nutrition [55, 56]. For example, AM can protect plant root and improve plant nutrient absorption capacity $[57,58]$. Meanwhile, its variability depends on soil depth [59], same as our result. Pathogens in subsoil were higher than topsoil, which harms other fungal community members This finding corresponds to a previous study, in which the relative abundance of soil pathogenic fungi increased with increasing soil depth [45].

The ecological network of biological communities has been extensively studied in animal and plant ecology and has recently received microbial ecology attention. However, current research provides insights into the effect of straw retention on changes in fungal communities, with a focus on soil depth.
Our findings revealed that the fungal community network in straw retention and topsoil revealed negative edges and modularity network (Table S7). If the degree of modularity of the two networks exceeds 0.4 , it indicates that these networks are modular [60]. Many studies have shown that the existence of modularity and negative interactions enhance the stability of disturbed networks [61-64]. The AveCC of SR treatment and topsoil were higher than $\mathrm{CK}$ and subsoil, showing that there were more potential connections and small-world behavior. In a small-world network, more OTUs could be available to all other OTUs via a comparatively short path [65]. On the contrary, the more connected the network is, the more it can contribute to effective and efficient carbon utilization [65]. Betweennes centrality scores indicates how often a node is found on the shortest path between two nodes in the network to connect it to each other, the higher number, the more connected they are. Network analysis showed that Ascomycota was identified as the main phylum for straw retention and soil depth, indicating that they played an important role in maintaining the function and structure of the ecological community. Keystone taxa were correlated with the $\mathrm{C}$ and $\mathrm{N}$ cycle in the CK and SR treatments. In the CK treatment, the number of Pleosporales was higher in the CK than SR. Species of Pleosporales occurred in various habitats, that can be epiphytes, endophytes or parasites of living leaves or stems, hyperparasites on fungi or insects, lichenized, or are saprobes of dead plant stems, leaves or bark) [66]. While Hypocreales order was present in SR treatment. Sordariomycetes are soft-rot fungi, which are well known to effectively decompose organic substrates such as cellulose, cellobiose and lignin [67].

These results showed that the keystone taxa were involved in various carbon and nitrogen substrates, such as TN, TC/TN, DOC, and DOC/DON, P cycle and AP utilization. This finding is consistent with previous studies documenting that different soils can support different fungal flora [68]. Hypocreales, which belongs to the patotroph, were also reported to be negatively correlated with TN and DOC [69]. A previous study indicated that environmental factors, such as TN, DOC, and DOC/ DON were unfavorable conditions for Hypocreales, and also postulated that excess nutrients decreased chlamydospore production [70]. In a related study, Glomerales, which belongs to arbuscular mycorrhiza fungi (AMF) [71], was associated with a high amount of available P, which in turn boosted plant growth [58]. Additionally, Auriculariales and Sordariales are generally considered saprophytic fungi [72], which stimulate the decomposition of organic substrates by saprotrophic fungi [73]. 


\section{Conclusions}

This study, we demonstrated that the fungal community composition, function, and co-occurrence pattern changed significantly in response to straw retention throughout the soil profile. The straw retention increased the diversity and abundance of fungi in $0-10 \mathrm{~cm}$ soil depth. Both straw retention and topsoil had a decreasing effect on the abundance of pathogens. Straw retention and depth of soil influenced the keystone taxa. Overall, these findings enhance our understanding of fungal metabolic functions and networks under straw retention in different soil profiles.

\section{Materials and methods}

\section{Field site and experiment design}

Short-term (14 months) experiment using sugarcane straw retention started in March 2017 at the Sugarcane Research Center of Fujian Agriculture and Forestry University, Fuzhou, Fujian Province, China (latitude: $26^{\circ} 05^{\prime} 9.60^{\prime \prime} \mathrm{N}$; longitude: $119^{\circ} 14^{\prime} 3.60^{\prime \prime} \mathrm{E}$ ) in the fallow ecosystem. The site has a clay loam texture, an annual average temperature of $20^{\circ} \mathrm{C}$ and rainfall of $1369 \mathrm{~mm}$ with a subtropical monsoon climate. The data of soil biological properties showed in our published research [18]. The sugarcane straw used in this study was collected from an adjacent sugarcane field, and crushed into small pieces. Two treatments, e.g., (i) control (CK), moldboard plow at $40 \mathrm{~cm}$ depth in the fallow field without sugarcane straw retention; and (ii) sugarcane straw retention (SR), moldboard plow at $40 \mathrm{~cm}$ depth in a fallow field with $30 \mathrm{tha}^{-1}$ of sugarcane straw retention were laid out, with three replicates. After SR, all field plots remained unplanted for1 year without any fertilization.

In May 2018, five sampling points were randomly taken from each plot and homogenized as one mixed sample. Based on the soil profile, soil samples were collected at depth $0-10,10-20,20-30$, and 30-40 cm. Finally, a total of 24 soil samples were obtained from the experiment site and taken to the laboratory on ice. Samples were mixed thoroughly and sieved $(2 \mathrm{~mm})$, and divided into parts. A portion of the fresh soil was air-dried to measure soil physiochemical properties. Furthermore, approximately $50 \mathrm{~g}$ of soil was packed into a sterile bag, and stored at $-80^{\circ} \mathrm{C}$.

\section{DNA extraction}

The total genomic DNA was extracted from $0.5 \mathrm{~g}$ newly collected soil with three replicates using the Fast DNA ${ }^{\text {тx }}$ Spin Kit (MP Biomedicals, LLC, Santa Ana, USA) according to the manufacturer's instructions. DNA concentration and quality were measured by calculating their absorbance (A260 and $280 \mathrm{~nm}$ ) using BioTek Synergy H1 Hybrid Multi-Mode Microplate Reader
(BioTek, USA). DNA was diluted with sterile water to a final concentration of $20 \mathrm{ng} \mu \mathrm{L}^{-1}$ for qRT-PCR. The integrity of the DNA extracts was ensured by electrophoresis and was stored at $-80^{\circ} \mathrm{C}$ awaiting sequencing.

\section{qRT-PCR}

The qRT-PCR method was employed to quantify soil fungi abundance using the primer set ITS1-F (5' -CTTG GTCATTTAGAGGAAGTAA-3') [74] and ITS4-R (5' TCCTCCGCTTA- TTGATATGC-3') [75] and SYBR Green detection (FastFire qPCR PreMix, TianGen Biotech, China). The standard for calculating the ITS rRNA gene quantity was developed from a clone with the correct insert. A plasmid DNA was generated from the clone using the pEASY ${ }^{\oplus}$-T1 Simple Cloning Kit (Transgene, China). The $\mathrm{R}^{2}$ of the standard curve was $>0.99$. The qRT-PCR reactions were carried out using each extracted DNA sample.

\section{Illumina MiSeq sequencing}

The amplification of the hypervariable ITS3-4 region of the ITS rRNA gene was carried out using fungal primers set ITS3F (GCATCGATGAAGAACGCAGC) and ITS4R (TCCTCCGCTTATTGATATGC) [76]. The PCR reactions were carried out in a $50 \mu \mathrm{L}$ mixture with $1 \mathrm{mM}$ dNTPs, $1 \times$ PCR buffer, $1 \mathrm{U}$ Platinum Taq, $5 \mu \mathrm{M}$ per primer, and $10 \mathrm{ng}$ of template DNA. The PCR amplification included an initial denaturation at $94{ }^{\circ} \mathrm{C}$ for 3 min, denaturation $\left(5\right.$ cycles at $94{ }^{\circ} \mathrm{C}$ ) for $30 \mathrm{~s}$, annealing at $45{ }^{\circ} \mathrm{C}$ for $20 \mathrm{~s}$, extension at $65^{\circ} \mathrm{C}$ for $30 \mathrm{~s}$, denaturation $\left(20\right.$ cycles at $94^{\circ} \mathrm{C}$ ) for $20 \mathrm{~s}$, annealing at $55^{\circ} \mathrm{C}$ for $20 \mathrm{~s}$, extension at $72^{\circ} \mathrm{C}$ for $30 \mathrm{~s}$ and a final extension at $72{ }^{\circ} \mathrm{C}$ for $5 \mathrm{~min}$. After purification and quantification, the PCR product of the ITS3-4 region of the ITS rRNA gene was determined by pyrosequencing using an Illumina MiSeq sequencer (Sangon Biotech Shanghai Co., Ltd., China) $[18,77]$.

\section{Processing and analyzing of sequencing data}

Both QIIME (version 1.17) software package and UPARSE software (version 7.1) was used to process raw sequences [78]. Sequences quality score $<20$, length $<$ $250 \mathrm{bp}$, or reads containing ambiguous characters were removed. After overlapped, sequences more than $10 \mathrm{bp}$ in size were assembled based on their sequence overlaps, unassembled sequence reads were eliminated, and sequences with $\geq 97 \%$ similarity were clustered into operational taxonomic units (OTUs), while chimeric sequences were identified and eliminated through the UCHIME method [79]. For each OTU, representative sequences were chosen for each OUT. A Ribosomal Database Project (RDP) classifier [80] was adopted to annotate the taxonomic information for each representative sequence. The species richness (ACE and Chao1 
indexes) [81, 82], number of observed OTUs, and diversity (Shannon index) [83] were used to calculate fungal abundance, diversity and communities in each soil sample using the Mothur pipeline [84]. Nonmetric multidimensional scale (NMDS) analysis was carried out to assess the variation in fungal community structure across the different soil layers $[19,85]$. Environmental factors were filtered with VIF (Variance Inflation Factor), factors greater than 10 were removed multiple times until the VIF values corresponding to the selected. Analysis of similarity (ANOSIM) was conducted to estimate the dissimilarity in the fungal community structures with treatments (CK and SR, $0-20 \mathrm{~cm}$ and $20-40 \mathrm{~cm}$ depths) using unweighted UniFrac dissimilarities. Furthermore, a distance-based redundancy analysis (db-RDA) was also used to examine the impact of soil physiochemical properties (Table S1) on fungal community composition among the different soil layers [18]. Pearson's correlation analysis was separately determined for treatments (CK, SR and topsoil, subsoil) to investigate the interaction among soil physiochemical properties and fungal order taxa, using R-software 3.5.2. The test data were analyzed using ANOVA by IBM SPSS Statistics software, and the difference between the mean values of each treatment was compared by Tukey's procedure at a 5\% level [19].

\section{FUNGuild analysis}

Fungi community function was investigated using FUNGuild to identify the functional groups (guilds) in the straw retention experiment. Fungi functional guild of was carried out using FUNGuild v1.0 [26], which taxonomically parsed fungal OTUs by examining the ecological guild of sequencing databases. Three trophic modes, for example, saprotrophs pathotrophs, and symbiotrophs are widely well-defined types in the fungal community ecology as they determine the specific fungi feeding habits. Twelve guilds related to these trophic modes were categorized. The Guilds that were "highly probable" and "probable" in the assignments were selected for not over-interpreting their data ecologically. OTUs of each sample that did not match taxa in the database were categorized as "unassigned".

\section{Network analysis}

Dynamic networks have great visualizations benefits, which depict ideas and concepts not immediately visible in a sociogram static. To minimize the complexity, only abundant OTUs with a proportion of total reads over $0.01 \%$ were retained in the OTUs table. OTUs table was then analyzed using $\mathrm{R}$ software 3.5.2 with the packages "psych" for the correlation matrix. The correlation matrix table result was submitted in Gephi. Gephi, is an interactive visualization and exploration platform used for complex systems graphs and many networks $[86,87]$.
Betweenness centrality (BC) was employed to determine the importance of the network structure, and high $\mathrm{BC}$ scores were very essential in sustaining the connectivity of an ecological network and matched them with key keystone species $[88,89]$. Modularity analysis determines how well a network may be separated into smaller clusters, or modules [89], and can be very important in identifying fungi community structure. High modularity depicts a network higher rate of intra-module edges relative to inter-module ones [90]. Gephi uses a modularity algorithm called the Louvain method, developed by Blondel and colleagues (2008) to find communities in the network [91].

\section{Supplementary Information}

The online version contains supplementary material available at https://doi. org/10.1186/s12866-021-02115-3.

\begin{abstract}
Additional file 1: Table S1. Soil physiochemical properties at different depths. Table S2. The copies number of ITS rRNA gene at $0-40-\mathrm{cm}$ depths. Table S3. Distribution of the number of tags across the soil samples. Table S4. Relative abundances of the fungal phyla at different depths. Table S5. The ANOSIM result of pairwise comparison. Table S6. The Composition proportion of fungal functional groups (guilds) inferred by FUNGuild. Table S7. Properties of fungal co-occurrence networks. Table S8. Variation in fungal functional group compositions of fungal communities at the genus level. Table S9. Variation in fungal functional group compositions of fungal communities at the order level. Figure S1. Extended error bar graphs indicate the significant difference of fungal functional guilds with control and straw retention treatment in topsoil $(0-20 \mathrm{~cm})(p<0.05$, average proportion, $n=3)$. The points depict variations between the "CKO-20" and "SRO-20", the values on the right-hand indicate the $p$-values obtained from the Welch t-test. CK, control; SR, sugarcane straw retention. Figure S2. Co-occurrence networks with (a) CKO20, (b) SRO-20, (c) CK20-40, and (d) SR20-40 of the fungal communities in the soil samples. CK, control; SR, sugarcane straw retention. Figure $\mathbf{S 3}$. Pearson's correlation coefficients of soil physiochemical properties and the keystone taxa of a network (genus), (a) non-straw retention, (b) straw retention, and (c) topsoil $(0-20 \mathrm{~cm})$, and (d) subsoil $(20-40 \mathrm{~cm})$ depths. The heatmap cells marked by "**" or "**" are statistically significant: * $p<$ 0.05 and ${ }^{* *} p<0.01$
\end{abstract}

\section{Abbreviations \\ CK: Control; SR: Sugarcane straw retention; HTS: High throughput sequencing; ANOSIM: Analysis of similarities; AM: Arbuscular mycorrhizal; avgK: Average degree; aveCC: Average clustering coefficients; \\ NMDS: Nonmetric multidimensional scale; RDP: Ribosomal Database Project; VIF: Variance Inflation Factor; db-RDA: distance-based redundancy analysis; OTU: Operational Taxonomic Units; rRNA: Ribosomal RNA; PCR: Polymerase Chain Reaction; ANOVA: Analysis of Variance}

\section{Acknowledgments}

We acknowledge the research was funded by the Earmarked Fund for China Agriculture Research System via grant number CARS-17. We want to praise the donor agencies of China for supporting this project.

\section{Authors' contributions}

All authors contributed to intellectual input and assisted in this study and manuscript preparation. C.Z., H.Z., Z.L., A.Y.A., Z.Z., and J. L. designed the research and conducted the experiments. C.Z., Z.L., S.L., N.F., J. L., Z.Z., and M.T. analyzed the data. C.Z., N.F., Y.Q. and M.T. wrote the manuscript. Y.Q. and H.Z. reviewed the manuscript. H.Z. supervised the work and approved the manuscript for publication. The author(s) read and approved the final manuscript. 


\section{Funding}

This research was funded by the Earmarked Fund for China Agriculture Research System (CARS-17).

\section{Availability of data and materials}

All datasets are presented in the main text and the additional file. The raw sequence data on ITS rDNA gene amplicons have been submitted to the NCBI Sequence Read Archive (SRA) database (Accession Number: SRP289388). The dataset analyzed during the current study is available from the corresponding author on reasonable request. [https://dataview.ncbi.nlm. nih.gov/object/PRJNA671590].

\section{Ethics approval and consent to participate}

Not applicable.

\section{Consent for publication}

Not applicable.

\section{Competing interests}

The authors declare that they have no competing interests.

\section{Author details}

${ }^{1}$ Key Laboratory of Sugarcane Biology and Genetic Breeding, Ministry of Agriculture, Fujian Agriculture and Forestry University, Fuzhou 350002, China. ${ }^{2}$ College of Agriculture, Fujian Agriculture and Forestry University, Fuzhou 350002, China. ${ }^{3}$ Fuzhou No.8 High School, Fuzhou 350000, China.

\section{Received: 9 October 2020 Accepted: 4 February 2021}

\section{Published online: 17 February 2021}

\section{References}

1. Tayyab M, Islam W, Arafat Y, Pang Z, Zhang C, Lin Y, et al. Effect of sugarcane straw and goat manure on soil nutrient transformation and bacterial communities. Sustainability. 2018;10(7):2361 Basel.

2. Tayyab M, Islam W, Lee CG, Pang Z, Khalil F, Lin S, et al. Short-term effects of different organic amendments on soil fungal composition. Sustainability. 2019;11(1):198 Basel.

3. Akhtar K, Wang W, Ren G, Khan A, Yang G. Changes in soil enzymes, soil properties, and maize crop productivity under wheat straw mulching in Guanzhong, China. Soil Tillage Res. 2018;182:94-102.

4. Ju XT, Xing GX, Chen XP, Zhang SL, Zhang LJ, Liu XJ, et al. Reducing environmental risk by improving $\mathrm{N}$ management in intensive Chinese agricultural systems. Proc Natl Acad Sci U S A. 2009;106(9):3041-6.

5. Barak $P$, Jobe $B O$, Krueger AR, Peterson LA, Laird DA. Effects of long-term soil acidification due to nitrogen fertilizer inputs in Wisconsin. Plant Soil. 1997;197(1):61-9.

6. Paungfoo-Lonhienne C, Yeoh YK, Kasinadhuni NRP, Lonhienne TGA Robinson N, Hugenholtz $P$, et al. Nitrogen fertilizer dose alters fungal communities in sugarcane soil and rhizosphere. Sci Rep-Uk. 2015;5(1): 8678.

7. Li H, Wang H, Wang $H$, Xin $P, X u X, M a Y$, et al. The chemodiversity of paddy soil dissolved organic matter correlates with microbial community at continental scales. Microbiome. 2018;6(1):187.

8. Lourenço KS, Suleiman AKA, Pijl A, Veen JAV, Cantarella H, Kuramae EE. Resilience of the resident soil microbiome to organic and inorganic amendment disturbances and to temporary bacterial invasion. Microbiome. 2018;6(1):142.

9. Banerjee S, Kirkby CA, Schmutter D, Bissett A, Kirkegaard JA, Richardson AE. Network analysis reveals functional redundancy and keystone taxa amongst bacterial and fungal communities during organic matter decomposition in an arable soil. Soil Biol Biochem. 2016;97:188-98.

10. Marschner P, Umar S, Baumann K. The microbial community composition changes rapidly in the early stages of decomposition of wheat residue. Soil Biol Biochem. 2011;43(2):445-51.

11. Benbi DK, Brar K, Toor AS, Sharma S. Sensitivity of labile soil organic carbon pools to long-term fertilizer, straw and manure management in rice-wheat system. Pedosphere. 2015;25(4):534-45.

12. Grandy AS, Salam DS, Wickings K, McDaniel MD, Culman SW, Snapp SS. Soil respiration and litter decomposition responses to nitrogen fertilization rate in no-till corn systems. Agric Ecosyst Environ. 2013;179:35-40.
13. Powlson DS, Riche AB, Coleman K, Glendining MJ, Whitmore AP. Carbon sequestration in European soils through straw incorporation: limitations and alternatives. Waste Manag. 2008;28(4):741-6.

14. Navarro-Noya YE, Gómez-Acata S, Montoya-Ciriaco N, Rojas-Valdez A, Suárez-Arriaga MC, Valenzuela-Encinas C, et al. Relative impacts of tillage, residue management and crop-rotation on soil bacterial communities in a semi-arid agroecosystem. Soil Biol Biochem. 2013;65:86-95.

15. Li C, Yan K, Tang L, Jia Z, Li Y. Change in deep soil microbial communities due to long-term fertilization. Soil Biol Biochem. 2014;75:264-72.

16. Will C, Thurmer A, Wollherr A, Nacke H, Herold N, Schrumpf M, et al. Horizon-specific bacterial community composition of german grassland soils, as revealed by pyrosequencing-based analysis of $16 \mathrm{~s}$ rRNA genes. Appl Environ Microbiol. 2010;76(20):6751-9.

17. Li X, Wang H, Li X, Li X, Zhang H. Distribution characteristics of fungal communities with depth in paddy fields of three soil types in China. $J$ Microbiol. 2020;58(4):279-87.

18. Zhang C, Tayyab M, Abubakar AY, Yang Z, Pang Z, Islam W, et al. Bacteria with different assemblages in the soil profile drive the diverse nutrient cycles in the sugarcane straw retention ecosystem. Diversity. 2019;11(10):194 BASEL.

19. Gu Y, Wang Y, Lu SE, Xiang Q, Yu X, Zhao K, et al. Long-term fertilization structures bacterial and archaeal communities along soil depth gradient in a paddy soil. Front Microbiol. 2017;81516.

20. Fritze H, Pietikinen J, Pennanen T. Distribution of microbial biomass and phospholipid fatty acids in Podzol profiles under coniferous forest. Eur J Soil Sci. 2010;51(4):565-73.

21. Blume E, Bischoff M, Reichert JM, Moorman T, Konopka A, Turco RF. Surface and subsurface microbial biomass, community structure and metabolic activity as a function of soil depth and season. Appl Soil Ecol. 2002;20(3): 171-81.

22. Crowther TW, Boddy L, Hefin, et al. Functional and ecological consequences of saprotrophic fungus-grazer interactions. ISME J. 2012;6(11):1992-2001.

23. Nie S, Lei $X$, Zhao L, Brookes PC, Wang F, Chen C, et al. Fungal communities and functions response to long-term fertilization in paddy soils. Appl Soil Ecol. 2018;130:251-8.

24. Toju H, Tanabe AS, Sato H. Network hubs in root-associated fungal metacommunities. Microbiome. 2018;6(1):116.

25. Dipak SP, Daniel S, Yin C, Scot H, Timothy P, Sabrina S. Long-term no-till: a major driver of fungal communities in dryland wheat cropping systems. PLoS One. 2017;12(9):e184611.

26. Nguyen NH, Song Z, Bates ST, Branco S, Tedersoo L, Menke J, et al. FUNGuild: an open annotation tool for parsing fungal community datasets by ecological guild. Fungal Ecol. 2016;20:241-8.

27. LaMondia JA, Gent M, Ferrandino FJ, Elmer WH, Stoner KA. Effect of compost amendment or straw mulch on potato early dying disease. Plant Dis. 1999:83(4):361-6.

28. Donovan NJ, Backhouse D, Burgess LW. Enhanced suppression of Gaeumannomyces graminis var. tritici by retention of residues in a cereal cropping system. Australas Plant Path. 2006;35(1):43-8.

29. Rodgers Gray BS, Shaw MW. Substantial reductions in winter wheat diseases caused by addition of straw but not manure to soil. Plant Pathol. 2000;49(5): 590-9.

30. Chen C, Zhang J, Min L, Qin C, Shen Q. Microbial communities of an arable soil treated for 8 years with organic and inorganic fertilizers. Biol Fertil Soils. 2016:52(4):1-13.

31. Davide F, Elke S, Guillaume L, Tesfaye W, Ois BF, Thomas R. Mineral vs. Organic amendments: Microbial community structure, activity and abundance of agriculturally relevant microbes are driven by long-term fertilization strategies. Front Microbiol. 2016:7:1446

32. Sun R, Dsouza M, Gilbert JA, Guo X, Wang D, Guo Z, et al. Fungal community composition in soils subjected to long-term chemical fertilization is most influenced by the type of organic matter. Environ Microbiol. 2016;18:5137-50.

33. Bahram M, Harend $H$, Tedersoo L. Network perspectives of ectomycorrhizal associations. Fungal Ecol. 2014;7(1):70-7.

34. Toju H, Yamamichi M, Guimar Es PR, Olesen JM, Mougi A, Yoshida T, et al. Species-rich networks and eco-evolutionary synthesis at the metacommunity level. Nat Ecol Evol. 2017;1(2):24.

35. Toju H, Yamamoto S, Tanabe AS, Hayakawa T, Ishii HS. Network modules and hubs in plant-root fungal biomes. J R Soc Interface. 2016;13(116): 20151097. 
36. Mandyam K, Jumpponen A. Seeking the elusive function of the rootcolonising dark septate endophytic fungi. Stud Mycol. 2005;53:173-89.

37. Toju H, Guimaraes PR, Olesen JM, Thompson JN. Assembly of complex plant-fungus networks. Nat Commun. 2014;5:5273.

38. Buee M, Reich M, Murat C, Morin E, Nilsson RH, Uroz S, et al. 454 pyrosequencing analyses of forest soils reveal an unexpectedly high fungal diversity. New Phytol. 2009;184(2):449-56.

39. Peay KG, Kennedy PG, Talbot JM. Dimensions of biodiversity in the earth mycobiome. Nat Rev Microbiol. 2016;14(7):434-47.

40. Zhu J, Peng H, Ji X, Li C, Li S. Effects of reduced inorganic fertilization and rice straw recovery on soil enzyme activities and bacterial community in double-rice paddy soils. Eur J Soil Biol. 2019;94:103116.

41. Fierer N, Schimel JP, Holden PA. Variations in microbial community composition through two soil depth profiles. Soil Biol Biochem. 2003;35(1):167-76.

42. Goyal S, Chander K, Mundra MC, Kapoor KK. Influence of inorganic fertilizers and organic amendments on soil organic matter and soil microbial properties under tropical conditions. Biol Fertil Soils. 1999; 29(2):196-200.

43. Huang W, Bai Z, Hoefel D, Hu Q, Lv X, Zhuang G, et al. Effects of cotton straw amendment on soil fertility and microbial communities. Front Env Sci Eng. 2012;6(3):336-49.

44. Chaer G, Fernandes M, Myrold D, Bottomley P. Comparative resistance and resilience of soil microbial communities and enzyme activities in adjacent native forest and agricultural soils. Microb Ecol. 2009;58(2):414-24.

45. Schlatter DC, Kendall K, Bryan C, Huggins DR, Timothy P. Fungal community composition and diversity vary with soil depth and landscape position in a no-till wheat-based cropping system. FEMS Microbiol Ecol. 2018;7:7.

46. Jumpponen A, Blair KLJA. Vertical distribution of fungal communities in tallgrass prairie soil. Mycologia. 2010;102(5):1027-41.

47. Toju H, Kishida O, Katayama N, Takagi K. Networks depicting the finescale co-occurrences of fungi in soil horizons. PLoS One. 2016;11(11): e165987.

48. Aislabie J, Deslippe JR, Dymond J. Soil microbes and their contribution to soil services. Soil Microbial Diversity. 2013;1(12):143-61.

49. Dymond JR. Ecosystem services in New Zealand: conditions and trends. Lincoln: Manaaki Whenua Press; 2013.

50. Blackwood CB, Waldrop MP, Zak DR, Sinsabaugh RL. Molecular analysis of fungal communities and laccase genes in decomposing litter reveals differences among forest types but no impact of nitrogen deposition. Environ Microbiol. 2007:9(5):1306-16.

51. Wang K, Yin X, Mao H, Chu C, Tian Y. Changes in structure and function of fungal community in cow manure composting. Bioresour Technol. 2018; 255:123-30.

52. Fan Chang FJRL. Changes in structure and function of bacterial and fungal communities in open composting of Chinese herb residues. Can Microbiol. 2020;66

53. Ottosson E, Nordén J, Dahlberg A, Edman M, Jönsson M, Larsson K, et al. Species associations during the succession of wood-inhabiting fungal communities. Fungal Ecol. 2014;11:17-28.

54. Anthony MA, Frey SD, Stinson KA. Fungal community homogenization, shift in dominant trophic guild, and appearance of novel taxa with biotic invasion. Ecosphere. 2017;8(9):e01951.

55. Igiehon NO, Babalola OO. Biofertilizers and sustainable agriculture: exploring arbuscular mycorrhizal fungi. Appl Microbiol Biotechnol. 2017;101(12): 4871-81.

56. Agarwal GP, Singh SM. Microascus cinereus infection of human nail. Indian J Med Sci. 1980;34(11):263-5.

57. Sikes BA, Klironomos KCAJ. Plant and fungal identity determines pathogen protection of plant roots by arbuscular mycorrhizas. J Ecol. 2009;97(6): 1274-80.

58. Li XL, George E, Marschner H. Extension of the phosphorus depletion zone in VAM white clover in a calcareous soil. Plant Soil. 1991;136(1):41-8.

59. Powers JS, Treseder KK, Lerdau MT. Fine roots, arbuscular mycorrhizal hyphae and soil nutrients in four neotropical rain forests: patterns across large geographic distances. New Phytol. 2005;165(3):913-21.

60. Deng $Y$, Jiang YH, Yang Y, He Z, Luo F, Zhou J. Molecular ecological network analyses. Bmc Bioinformatics. 2012;13:113.

61. Coyte KZ, Schluter J, Foster KR. The ecology of the microbiome: networks, competition, and stability. Science. 2015;350(6261):663-6.

62. Rooney N, McCann K, Gellner G, Moore JC. Structural asymmetry and the stability of diverse food webs. Nature. 2006;442(7100):265-9.
63. Stouffer DB, Bascompte J. Compartmentalization increases food-web persistence. Proc Natl Acad Sci U S A. 2011;108(9):3648-52.

64. De Vries FT, Griffiths Rl, Bailey M, Craig H, Girlanda M, Gweon HS, et al. Soil bacterial networks are less stable under drought than fungal networks. Nat Commun. 2018;9(1):3012-33.

65. Layeghifard M, Hwang DM, Guttman DS. Disentangling interactions in the microbiome: a network perspective. Trends Microbiol. 2017;25(3):217-28.

66. Kruys A, Wedin M. Phylogenetic relationships and an assessment of traditionally used taxonomic characters in the Sporormiaceae (Pleosporales, Dothideomycetes, Ascomycota), utilising multi-gene. Syst Biodivers. 2009; 7(04):465-78.

67. Wolfgang $\mathrm{H}$, Christoph $\mathrm{S}$, Augustin M, et al. Catalytic properties and classification of cellobiose dehydrogenases from ascomycetes. Appl Environ Microbiol. 2011;77:1804-15.

68. Chandrashekar MA, Pai KS, Raju NS. Fungal diversity of rhizosphere soils in different agricultural fields of Nanjangud Taluk of Mysore District, Karnataka, India. Int J Curr Microbiol App Sci. 2014;3(5):559-66.

69. Posada F, Aime MC, Peterson SW, Rehner SA, Vega FE. Inoculation of coffee plants with the fungal entomopathogen Beauveria bassiana (Ascomycota: Hypocreales). Mycol Res. 2007;111(6):748-57.

70. Ford EJ. Interaction of carbon nutrition and soil substances in chlamydospore formation by fusarium. Phytopathology. 1970;60(12): 1732

71. Franke T, Beenken L, Döring M, Kocyan A, Agerer R. Arbuscular mycorrhizal fungi of the Glomus-group a lineage (Glomerales; Glomeromycota) detected in myco-heterotrophic plants from tropical Africa. Mycol Prog. 2006;5(1):24-31.

72. Ikeda S, Rallos LEE, Okubo T, Eda S, Inaba S, Mitsui H, et al. Microbial community analysis of field-grown soybeans with different nodulation phenotypes. Appl Environ Microbiol. 2008;74(18):5704-9.

73. Rousk J, Baath E. Growth of saprotrophic fungi and bacteria in soil. FEMS Microbiol Ecol. 2011;78(1):17-30.

74. Gardes M, Bruns TD. ITS primers with enhanced specificity for basidiomycetes - application to the identification of mycorrhizae and rusts. Mol Ecol. 2008;2(2):113-8.

75. Seliger H. PCR protocols - a guide to methods and applications. New York: Academic Press; 1990.

76. White TJ. Amplification and direct sequencing of fungal ribosomal RNA genes for phylogenetics. Pcr Protocols. 1994

77. White T, Bruns T, Lee S, Taylor FJRM, White T, Lee SH, et al. Amplification and direct sequencing of fungal ribosomal RNA genes for phylogenetics. PCR Protocols. 1990.

78. Watanabe FS, Olsen SR. Test of an ascorbic acid method for determining phosphorus in water and nahco3 extracts from soil. Soil Sci Soc Am J. 1965: 29(6):677-8

79. Edgar RC, Haas BJ, et al. UCHIME improves sensitivity and speed of chimera detection. Bioinformatics. 2011;179:2194-200.

80. Wang Q, Garrity GM, Tiedje JM, Cole JR. Naive bayesian classifier for rapid assignment of rrna sequences into the new bacterial taxonomy. Appl Environ Microbiol. 2007;73(16):5264-7.

81. Chao A. Nonparametric estimation of the number of classes in a population. Scand.J.Statist. 1984;11:265-70.

82. Chao A. Estimating the number of classes via sample coverage. J Am Stat Assoc. 1992;87:210-7.

83. Keylock CJ. Simpson diversity and the Shannon-wiener index as special cases of a generalized entropy. Oikos. 2005;109(1):203-7.

84. Schloss PD, Westcott SL, Ryabin T, Hall JR, Hartmann M, Hollister EB, et al. Introducing mothur: open-source, platform-independent, communitysupported software for describing and comparing microbial communities. Appl Environ Microbiol. 2009;75:7537-41.

85. Legendre P, Gallagher ED. Ecologically meaningful transformations for ordination of species data. Oecologia. 2001;129(2):271-80.

86. Chu K, Wipfli H, Valente TW. Using visualizations to explore network dynamics. J Soc Struct. 2013;14:1.

87. Muhongya KV, Maharaj MS, editors. Visualising and analysing online social networks IEEE 2015, vol. 2015. p. 1-6.

88. Newman ME. Modularity and community structure in networks. Proc Natl Acad Sci U S A. 2006:103(23):8577-82

89. Newman MEJ, Girvan M. Finding and evaluating community structure in networks. Phys Rev E Stat Nonlinear Soft Matter Phys. 2004;69:26113. 
90. Wu L, Yang Y, Chen S, Zhao M, Zhu Z, Yang S, et al. Long-term successional dynamics of microbial association networks in anaerobic digestion processes. Water Res. 2016;104:1-10.

91. Blondel VD, Guillaume J, Lambiotte R, Lefebvre E. Fast unfolding of communities in large networks. J Stat Mech-Theory E. 2008;2008(10): 10008-12.

\section{Publisher's Note}

Springer Nature remains neutral with regard to jurisdictional claims in published maps and institutional affiliations.

Ready to submit your research? Choose BMC and benefit from:

- fast, convenient online submission

- thorough peer review by experienced researchers in your field

- rapid publication on acceptance

- support for research data, including large and complex data types

- gold Open Access which fosters wider collaboration and increased citations

- maximum visibility for your research: over $100 \mathrm{M}$ website views per year

At $\mathrm{BMC}$, research is always in progress.

Learn more biomedcentral.com/submissions 